ZBIGNIEW ANUSIK

Uniwersytet Łódzki

(iD) ORCID ID: 0000-0002-5483-4970
WŁA DZA I POLITYKA

W CZASACH NOWOŻYTNYCH

DYPLOMACJA I SPRAWY WEWNĘTRZNE

\title{
Kasztelan krakowski Jerzy ks. Zbaraski wobec zagrożenia granic Rzeczypospolitej ze strony Siedmiogrodu
}

\author{
Castellan of Kraków prince Jerzy Zbaraski towards \\ the threat to the borders of Polish-Lithuanian Commonwealth from Transylvania
}

J

erzy ks. Zbaraski był potomkiem starego wołyńskiego rodu kniaziowskiego. Urodził się w 1574 r. jako syn Janusza (zm. 1608), z czasem wojewody bracławskiego i Anny ks. Czetwertyńskiej (zm. 1581). Już w roku 1590 objął po ojcu grodowe starostwo pińskie w województwie brzesko-litewskim. W 1591 r. kniaź Jerzy wraz z młodszym bratem Krzysztofem (1579-1627) wyjechał w długą podróż zagraniczną. Bracia Zbarascy zwiedzili Niemcy, Włochy i Francję, a później również Węgry i Niderlandy. Studiowali w Padwie i Lowanium. Ich staranne wykształcenie było w swej formie i treści głownie włoskie i francuskie. Młodzi Zbarascy obracali się w środowiskach, które cechowała niechęć do Niemców, względna tolerancja religijna, swoboda badań naukowych i wrogość wobec jezuitów. Od dzieciństwa wychowani w wierze katolickiej, obyci w świecie, wykształceni i oczytani, pod względem intelektualnym obaj bracia zdecydowanie przewyższali ojca. Przesiąknięci kulturą zachodnią, bardzo aktywni w życiu politycznym, osiągnęli też w Rzeczypospolitej znaczenie, o jakim nie mógł marzyć stary wojewoda bracławski ${ }^{1}$.

Swoje wielkie znaczenie polityczne i niezwykłą popularność wśród szlachty zawdzięczali bracia Zbarascy nie tylko niewątpliwym talentom osobistym, ale i ogromnemu majątkowi odziedziczonemu po ojcu. O ile jednak książę Janusz gromadził dobra głównie na Wołyniu i Ukrainie, o tyle Jerzy i Krzysztof ks. Zbarascy zwrócili większą

${ }^{1}$ Por. W. Dobrowolska, Mtodość Jerzego i Krzysztofa Zbaraskich (z wstępem o rodzie Zbaraskich i życiorysem Janusza Zbaraskiego wojewody bractawskiego), Przemyśl 1927, s. 86-103, 121-134; Z. Anusik, Kasztelan krakowski Jerzy ks. Zbaraski (1574-1631). Szkic do portretu antyregalisty, „Przegląd Nauk Historycznych" 2010, R. IX, nr 1, s. 55-58. 
uwagę na ziemie leżące na zachód od ich rodzinnego Wołynia. Z biegiem czasu obaj uzyskali nadania licznych królewszczyzn na Rusi oraz na etnicznych ziemiach polskich. Do dóbr domeny królewskiej rychło dodali też prywatne dobra w Małopolsce. W Krakowie posiadali piękną renesansową kamienicę (zwaną pałacem), która stała się ich ulubioną rezydencją. Nie na Wołyniu i Ukrainie, ale właśnie w Małopolsce najczęściej też przebywali. Potęga majątkowa książąt Zbaraskich była bez wątpienia jednym z istotnych czynników wpływających na ich pozycję polityczną. Swoje znaczenie ugruntowali jednak przede wszystkim dzięki swojej działalności publicznej i prezentowanym przez siebie poglądom. Starszy z nich - książę Jerzy - był z pewnością najwybitniejszym przywódcą antykrólewskiej opozycji w drugiej połowie panowania Zygmunta $\mathrm{III}^{2}$.

Długo pomijany przez króla w rozdawnictwie wakansów, dopiero w 1612 r., w wieku 38 lat, otrzymał książę Jerzy Zbaraski urząd krajczego koronnego. Nie od razu jednak ambitny magnat zdecydował się na przejście do otwartej opozycji. Przesądził o tym dopiero głośny konflikt Zbaraskich z wojewodą kijowskim i hetmanem polnym koronnym Stanisławem Żółkiewskim. Dumni książęta otwarcie oskarżyli hetmana o nieudolność i obwiniali go o nieporządki panujące na kresach. Mieli zresztą ku temu powody, gdyż ich wołyńskie i ukraińskie dobra były ustawicznie pustoszone przez Tatarów (z którymi Żółkiewski nie potrafił walczyć), Kozaków i bandy niepłatnego żołnierza. Na pogłębiającą się niechęć potężnych magnatów do starego hetmana wpływ miał również zawarty przez niego 23 września 1617 r. traktat z Turkami pod Buszą, który pozbawiał Rzeczpospolitą wszelkiego wpływu na sprawy księstw naddunajskich. Oliwy do ognia dodał sam Zygmunt III, który na sejmie roku 1618 wyniósł Żółkiewskiego (awansowanego wcześniej na hetmana wielkiego) do godności kanclerza wielkiego koronnego, a inne wakanse rozdzielił pomiędzy jego politycznych przyjaciół. Książęta ze Zbaraża (Jerzy zabiegał o pieczęć wielką koronną, a Krzysztof o urząd podkomorzego koronnego) zostali całkowicie pominięci ${ }^{3}$.

We wrześniu 1618 r., w obliczu spodziewanego najazdu tatarskiego, obaj bracia Zbarascy przyprowadzili swoje poczty do obozu hetmana pod Orynin, ale - podobnie jak inni możnowładcy kresowi - nie chcieli podporządkować się jego rozkazom. W efekcie spory i niesnaski w polskim obozie sparaliżowały działania całej armii. Wojsko siedziało bezczynnie w obozie, a tymczasem Tatarzy wymknęli się spod Orynina, rozpuścili

${ }^{2}$ W kwestii posiadłości ziemskich książąt na Zbarażu por. Z. Anusik, Latyfundia książąt Zbaraskich w XVI i XVII wieku, „Przegląd Nauk Historycznych” 2009, R. VIII, nr 1, s. 17-77; idem, Zbarascy i Kalinowscy. Karta z dziejów wielkiej wtasności ziemskiej na kresach Rzeczypospolitej w pierwszej potowie XVII wieku, [w:] Między Zachodem a Wschodem, t. III (Etniczne, kulturowe i religijne pogranicza Rzeczypospolitej $w$ XVI-XVIII wieku), red. K. Mikulski, A. Zielińska-Nowicka, Toruń 2006, s. 74-97. Por. też idem, Kasztelan krakowski Jerzy ks. Zbaraski, s. 56-61.

3 Por. J. Wolff, Kniaziowie litewsko-ruscy od końca XIV wieku, Warszawa 1895, s. 618; W. Dobrowolska, Książęta Zbarascy w walce z hetmanem Żótkiewskim, Kraków 1930, s. 9-17; Z. Ossoliński, Pamiętnik, oprac. J. Długosz, Warszawa 1983, s. 83-91; Z. Anusik, Kasztelan krakowski Jerzy ks. Zbaraski, s. 63-64. 
zagony i spustoszyli ogromną połać bezbronnego kraju. Dobra Zbaraskich ponownie zostały złupione. Kompromitująca dla Żółkiewskiego kampania orynińska ściągnęła na niego gromy potępienia. Wiele pism atakujących i szkalujących starego hetmana powstało w najbliższym otoczeniu braci Zbaraskich. Jest pewne, że niektóre z nich były ich własnego autorstwa. Jest też sprawą oczywistą, że bezpardonowe ataki na Żółkiewskiego tylko utwierdziły tego ostatniego w niechęci do dumnych książąt ${ }^{4}$.

Na sejmie 1619 r. hetman Żółkiewski musiał się tłumaczyć ze swojej bezczynności pod Oryninem. Rozgoryczony, zgłosił nawet gotowość złożenia buławy. Był to jednak jedynie pusty gest z jego strony, gdyż zarówno król, jak i senatorowie regaliści wystąpili z gorącą obroną jego zasług i dokonań. Ponieważ zaś Zygmunt III ponownie zignorował wysuwane przez posłów żądanie rozdania wakansów, prowadzona przez Jerzego ks. Zbaraskiego opozycja zablokowała inicjatywy ustawodawcze dworu i sprawiła, że sejm roku 1619 rozszedł się bez podjęcia jakichkolwiek konstruktywnych uchwał. Pomimo zdecydowanie opozycyjnej postawy księcia Jerzego, 6 czerwca tego samego roku Zygmunt III obdarzył go urzędem podczaszego koronnego. W kolejnych miesiącach starszy z braci Zbaraskich nie zmienił jednak bynajmniej swoich poglądów i zdecydowanie potępiał politykę króla i hetmana. Za wielki błąd polityczny uważał próby mieszania się Rzeczypospolitej do wojny trzydziestoletniej i zabiegi Zygmunta III o odzyskanie Śląska. Bezwzględnie krytykował też pomoc króla dla Habsburgów zagrożonych przez wojska powstańców czeskich i sprzymierzonego z nimi władcy Siedmiogrodu Bethlena Gábora (Gabriela Bethlena). Ze szczególnym potępieniem ze strony księcia spotkało się jednak posłanie do Siedmiogrodu oddziałów lisowczyków, które pobiły pod Humiennem (23 XI 1619) korpus Jerzego I Rakoczego i zmusiły Bethlena Gábora do odstąpienia od murów Wiednia. W początkach następnego roku książę Jerzy z dużą dozą przenikliwości ostrzegał małopolską szlachtę, że pomoc udzielona cesarzowi może narazić Rzeczpospolitą na odwetową wyprawę turecką. Nie szczędził też słów dezaprobaty dla prohabsburskiej polityki dworus.

Niefortunna wyprawa do Mołdawii, klęska cecorska i śmierć hetmana Żółkiewskiego po rozbiciu przez Tatarów polskiego taboru pod Mohylewem (6 X 1620) znowu ściągnęły gromy potępienia na politykę królewską. Dobrą okazją do wytoczenia zarzutów pod adresem Zygmunta III i zmarłego hetmana stały się obrady sejmu, który obradował w Warszawie od 3 listopada do 11 grudnia tego samego roku. I znowu bracia Zbarascy stanęli na czele antykrólewskiej opozycji. Pod wpływem ostrych wystąpień

${ }^{4}$ Por. W. Dobrowolska, Książęta Zbarascy, s. 25-41; Z. Ossoliński, Pamiętnik, s. 110-112; Z. Anusik, Kasztelan krakowski Jerzy ks. Zbaraski, s. 66-67.

5 Por. J. Wolff, Kniaziowie litewsko-ruscy, s. 618; W. Dobrowolska, Ksią̇ęta Zbarascy, s. 46-53; Z. Ossoliński, Pamiętnik, s. 118-120; F. Kudelka, Bitwa pod Humiennem, „Przegląd Powszechny” 1902, t. LXXXV, s. 187-199; W. Biernacki, Biata Góra 1620, Gdańsk 2006, s. 233-244; Z. Anusik, Kasztelan krakowski Jerzy ks. Zbaraski, s. 67-69. 
poselskich dwór musiał się tłumaczyć zarówno z wyprawy mołdawskiej Żółkiewskiego, jak i z wysłania lisowczyków do Siedmiogrodu. Z inspiracji Zbaraskich podniesiono także po raz kolejny sprawę wakansów (śmierć Żółkiewskiego sprawiła bowiem, iż należało pomyśleć o obsadzeniu dwóch najważniejszych ministerstw - hetmaństwa wielkiego i kanclerstwa wielkiego koronnego). Ponieważ jeszcze przed rozpoczęciem obrad sejmu król nadał Jerzemu ks. Zbaraskiemu kasztelanię krakowską, wakującą po śmierci Janusza ks. Ostrogskiego, nie rozpatrywano jego kandydatury do kanclerstwa. Ostatecznie też kanclerzem wielkim koronnym został podkanclerzy Andrzej Lipski, a podkanclerstwo po nim otrzymał Wacław Leszczyński. Książę Jerzy natomiast tuż po zakończeniu obrad sejmowych (12 XII 1620) przyjął urząd kasztelana krakowskiego. Zrobił to z pewnością niezbyt chętnie, gdyż nominacja królewska zamknęła mu definitywnie drogę do upragnionego kanclerstwa wielkiego koronnego ${ }^{6}$.

Jako kasztelan krakowski, pierwszy świecki senator Rzeczypospolitej, Jerzy ks. Zbaraski poczuwał się do obowiązku doradzania królowi i recenzowania niemal wszystkich decyzji politycznych podejmowanych na dworze. Objęcie urzędu senatorskiego nie wpłynęło jednak w żaden sposób ani na poglądy, ani na postawę księcia Jerzego. Przez cały czas pozostawał zdeklarowanym opozycjonistą wobec rządów Zygmunta III i prawie zawsze występował przeciwko kolejnym inicjatywom politycznym króla. Dodajmy również, że Zbaraskiego cechowała rzadko spotykana odwaga cywilna. Nie wahał się mówić i pisać do króla wprost, bez owijania w bawełnę; przekazywał mu opinie przykre i całkowicie sprzeczne z jego poglądami. Można się jedynie domyślać, że arogancki, mentorski i pełen pychy ton wypowiedzi kasztelana krakowskiego musiał irytować króla i przyprawiać go o napady złości. Co przy tym wszystkim wydaje się ciekawe to fakt, że książę Jerzy nigdy nie popadł w całkowitą niełaskę. Zygmunt III musiał się bowiem liczyć z uwielbianym przez szlachtę magnatem, który był dla współczesnych ideałem senatora. Człowiekiem, którego podziwiano, i któremu wybaczano to, czego z pewnością nie wybaczono by innym ${ }^{7}$.

Wśród kwestii znajdujących się w kręgu zainteresowań Jerzego ks. Zbaraskiego były również problemy wynikające z sąsiedztwa z Siedmiogrodem. Na tronie tego księstwa, będącego lennem Turcji, od 1613 r. zasiadał Gabriel Bethlen. Był to władca energiczny i ambitny, który przeprowadził w Siedmiogrodzie wiele reform gospodarczych i finansowych. Wzmocnił władzę książęcą i znacznie powiększył dochody skarbu. Jako wyznawca kalwinizmu sympatyzował z powstańcami czeskimi i opozycją w rządzonym przez Habsburgów Królestwie Węgierskim. We wrześniu 1619 r. wojska siedmiogrodzkie

${ }^{6}$ Por. F. Suwara, Przyczyny i skutki klęski cecorskiej 1620 r., Kraków 1930; R. Majewski, Cecora rok 1620, Warszawa 1970; Z. Ossoliński, Pamiętnik, s. 125-128, 134-136; W. Dobrowolska, Książęta Zbarascy, s. 54-60; J. Wolff, Kniaziowie litewsko-ruscy, s. 618; Z. Anusik, Kasztelan krakowski Jerzy ks. Zbaraski, s. $69-70$.

7 Por. Z. Anusik, Kasztelan krakowski Jerzy ks. Zbaraski, s. 72, 136. 
ruszyły do walki przeciwko cesarzowi Ferdynandowi II. W tym samym miesiącu Siedmiogrodzianie opanowali Koszyce, a w październiku Preszburg (Bratysławę). W końcu listopada armia Bethlena Gábora wraz z sojuszniczymi oddziałami czeskimi, morawskimi i śląskimi rozpoczęła oblężenie Wiednia. Trudności aprowizacyjne, wybuch zarazy oraz wieści o klęsce oddziałów Jerzego I Rakoczego w bitwie pod Humiennem zmusiły jednak władcę Siedmiogrodu do odstąpienia od cesarskiej stolicy. Dnia 5 grudnia 1619 r. wojska Bethlena Gábora rozpoczęły odwrót w kierunku Preszburga. Zebrany w tym mieście sejm węgierski 15 stycznia 1620 r. zdetronizował Ferdynanda II, powierzył władzę na cesarskich Węgrzech Bethlenowi i przegłosował zawarcie sojuszu z powstańcami czeskimi. Już 4 lutego 1620 władca Siedmiogrodu zawarł jednak rozejm z cesarzem, który obowiązywać miał do września tego samego roku. Ferdynand II zyskiwał czas na przygotowanie ofensywy przeciwko buntownikom w państwach korony św. Wacława oraz w Dolnej i Górnej Austrii ${ }^{8}$.

Tymczasem 25 sierpnia 1620 r. stany węgierskie obradujące w Besztercebánya (Bańskiej Bystrzycy) obwołały Bethlena królem Węgier, ale ten nie zdecydował się na przeprowadzenie koronacji. Zadowolił się samym tytułem, chociaż używał go w ograniczonym zakresie. Na tym samym sejmie podjęto uchwałę o przystąpieniu Królestwa Węgierskiego do koalicji antyhabsburskiej. Po wygaśnięciu rozejmu, w początkach października 1620 r., władca Siedmiogrodu ponownie wysłał wojska przeciwko Ferdynandowi II. Dywersyjne uderzenie Węgrów na Wiedeń zostało jednak odparte, a przysłane przez Bethlena Gábora posiłki w niczym nie pomogły Czechom, których wojska zostały rozgromione w bitwie na Białej Górze 8 listopada tego samego roku. Wiosną roku 1621 wojska siedmiogrodzkie rozpoczęły odwrót w kierunku Koszyc. W początkach maja Preszburg został zajęty przez oddziały cesarskie. Węgierscy magnaci zaczęli przechodzić na stronę Ferdynanda II. Mimo tego, Gabriel Bethlen zawarł porozumienie z przywódcami powstania na Morawach oraz na Śląsku i postanowił kontynuować walkę z Habsburgami. Wszystkie swoje siły zamierzał skoncentrować w Koszycach'.

Wieści o poczynaniach władcy Siedmiogrodu wywołały poważne zaniepokojenie Jerzego ks. Zbaraskiego. W czerwcu 1621 r., w okresie przygotowań do odparcia spodziewanego najazdu tureckiego, kasztelan krakowski wskazywał na poważne zagrożenie Małopolski w przypadku, gdyby Turcy zdecydowali się uderzyć z dwóch stron na Rzeczpospolitą. Obawiał się, że sułtan może wysłać 200 tys. ludzi na Kamieniec, a sam z inną armią spod Belgradu może pójść na Eger i Koszyce, „a z Koszyc do Krakowa 26 mil drogami dobremi i przestronnemi, i kto by mu impediet, radbym to wiedział". Zdaniem Zbaraskiego, gdyby 10 tys. Tatarów znalazło się pod murami stolicy, zapaliwszy Kleparz i inne przedmieścia, „dymem i płomieniami wydusiliby Kraków wszystek”.

\footnotetext{
8 Por. W. Biernacki, Biata Góra, s. 202-208, 218-219, 221-223, 229-248; W. Felczak, Historia Wegier, wyd. 2, Wrocław 1983, s. 143-144.

9 Por. W. Biernacki, Biata Góra, s. 282-333.
} 
Książę pisał także, iż nawet w przypadku, gdyby sułtan poszedł z główną armią na Podole, to wystarczyłby atak ze strony władcy Siedmiogrodu lub jakiegoś pogranicznego paszy, aby Kraków dostał się w ręce Turków, „bo ani bronić, ani obronić [stolicy] nie masz podobieństwa żadnego"10.

W początkach lipca 1621 r. książę Jerzy informował króla o przyjeździe do Krakowa wysłannika stanów węgierskich. Zdaniem kasztelana krakowskiego, który przeprowadził z Węgrem długą rozmowę, skonfliktowani z Ferdynandem II Węgrzy chcieli zabiegać o pośrednictwo polskiego króla w swoich rokowaniach z cesarzem w sprawie przywrócenia pokoju i wycofania niemieckich załóg z węgierskich zamków. Wyrażali również ogromne zaniepokojenie możliwością wtargnięcia lisowczyków w granice Królestwa Węgierskiego. Jednocześnie wysłannik węgierskiego sejmu zapewniał Zbaraskiego (wyraźnie rozmijając się z prawdą), że stany nie ufają do końca Bethlenowi Gáborowi i nigdy nie wzywały pomocy tureckiej przeciwko Habsburgom. Powiedział mu także, że Turcy ściągają wszystkich swoich lenników do księstw naddunajskich, do głównej armii sułtańskiej, co zdawało się wykluczać możliwość dokonania przez nich ataku na Rzeczpospolitą od strony granicy węgierskiej. W konsekwencji książę Jerzy prosił króla o utrzymanie za wszelką cenę pokoju z Węgrami i powstrzymanie lisowczyków ${ }^{11}$.

Kilka dni później kasztelan krakowski w liście do króla ponownie powrócił do spraw podnoszonych już we wcześniejszej korespondencji. Oburzał się na zaciąganie lisowczyków do wojska koronnego. Jego poważny niepokój budziło skierowanie ich oddziałów nad granicę węgierską i rabunki dokonywane w województwach krakowskim i sandomierskim. Irytacja księcia Jerzego była tym większa, że kilkudziesięcioosobowy oddział lisowczyków najechał na jego dzierżawę szycką. Zdaniem kasztelana krakowskiego pojawienie się lisowczyków na granicy z Węgrami mogło mieć fatalne konsekwencje dla Rzeczypospolitej. Pogłoski o rychłym wkroczeniu Polaków miały bowiem ostatecznie przekonać stany węgierskie do utrzymania porozumienia z Bethlenem Gáborem i wezwania na pomoc Turków i Tatarów ${ }^{12}$.

W początkach sierpnia 1621 r. Jerzy ks. Zbaraski pisał do Zygmunta III, że wysłannik stanów węgierskich oddał mu kolejny list od swoich mocodawców oraz list

${ }^{10}$ J. Zbaraski do Zygmunta III, Kraków, 12 VI 1621, Listy księcia Jerzego Zbaraskiego kasztelana krakowskiego z lat 1621-1631, wyd. A. Sokołowski, Scriptores Rerum Polonicarum, t. V, Kraków 1880, s. 30-33. Warto w tym miejscu zwrócić uwagę na to, iż opracowany przez dowództwo tureckie pierwotny plan wojny z Polską rzeczywiście przewidywał uderzenie na Rzeczpospolitą z dwóch kierunków - z Mołdawii na Lwów i z Siedmiogrodu na Kraków. Na Lwów miał wyruszyć sam sułtan z głównymi siłami, a na Kraków Bethlen Gábor z Siedmiogrodzianami oraz posiłkami tureckimi i tatarskimi. Por. L. Podhorodecki, Jan Karol Chodkiewicz 1560-1621, Warszawa 1982, s. 311.

${ }^{11}$ J. Zbaraski do Zygmunta III, Kraków, 5 VII 1621, Listy księcia Jerzego Zbaraskiego, s. 35-36.

${ }_{12}$ J. Zbaraski do Zygmunta III, Kraków, 9 VII 1621, Listy księcia Jerzego Zbaraskiego, s. 37-38. 
od władcy Siedmiogrodu. Ten ostatni zapewniał Rzeczpospolitą o swojej przyjaźni i ostrzegał, że wojska tureckie i tatarskie ruszyły już w kierunku jej granic. Zbaraski nie wierzył w dobrą wolę Bethlena i uważał go za wiernego lennika sułtana, a zatem wroga Rzeczypospolitej i całego chrześcijaństwa. I chociaż w owym czasie książę Jerzy był już pewien, że Węgrzy zdecydowali się kontynuować współpracę z księciem siedmiogrodzkim, radził jednak królowi, by wydał paszport wysłannikowi stanów węgierskich, „bo a cóż to zawadzi wysłuchać go co powie, a potem uczynić co aequitas et commodum Reipublicae requrit"13.

Tymczasem 9 października tego samego roku podpisano pokój chocimski, który kończył wojnę Rzeczypospolitej z Turcją. Bethlen Gábor zaś, nie odniósłszy poważniejszych sukcesów w wojnie z cesarzem, zdecydował się na rozpoczęcie negocjacji pokojowych. Dnia 31 grudnia 1621 r. zawarł w Nikolsburgu (Mikulovie) pokój z Ferdynandem II (ratyfikowany przez cesarza w Wiedniu 6 stycznia roku następnego). $\mathrm{Na}$ jego mocy Bethlen Gábor zrzekł się tytułu króla węgierskiego i zwrócił insygnia koronacyjne. W zamian za to uzyskał tytuł księcia Rzeszy Niemieckiej, a terytorium Siedmiogrodu zostało powiększone o siedem komitatów węgierskich nad górną Cisą. Ponadto Bethlen otrzymał księstwo opolsko-raciborskie na Śląsku i odszkodowanie w wysokości 50 tys. forintów. Już jednak w 1623 r. siedmiogrodzki książę zerwał pokój z Ferdynandem II i wtargnął na Morawy. I tym razem jednak nie udało mu się odnieść znacznych sukcesów. Na mocy rozejmu zawartego z cesarzem 20 stycznia 1624 r. w Besztercebánya (Bańskiej Bystrzycy) utracił księstwo opolsko-raciborskie. W dniu 24 maja tego samego roku podpisano natomiast traktat pokojowy w Wiedniu, który przywracał na Węgrzech postanowienia z Nikolsburga. Uwikłanie się władcy Siedmiogrodu w przedłużający się konflikt z Habsburgami przy jednoczesnym uregulowaniu stosunków Rzeczypospolitej z Turcją (poselstwo Krzysztofa ks. Zbaraskiego do Stambułu na przełomie roku 1622 i 1623) sprawiło, że książę Jerzy na dłuższy czas stracił zainteresowanie dla spraw rozgrywających się po drugiej stronie Karpat ${ }^{14}$.

Kasztelan krakowski musiał jednak utrzymywać jakieś stosunki z władcą Siedmiogrodu, o czym wiedziano w otoczeniu Zygmunta III. W początkach sierpnia 1625 r. pisał bowiem do Krzysztofa ks. Radziwiłła, współczując mu z powodu obwiniania go przez dwór o niepowodzenia w wojnie inflanckiej ze Szwecją. Radził mu ignorować wszystkie te oskarżenia i brać przykład z siebie,

${ }^{13}$ J. Zbaraski do Zygmunta III, Kraków, 2 VIII 1621, Listy księcia Jerzego Zbaraskiego, s. 39-40.

${ }_{14}$ Por. J. Tretiak, Historia wojny chocimskiej (1621), Kraków 1921; L. Podhorodecki, N. Raszba, Wojna chocimska 1621 r., Kraków 1979; Z. Anusik, Kasztelan krakowski Jerzy ks. Zbaraski, s. 78-79; idem, Cztery listy księcia Krzysztofa Zbaraskiego do prymasa Wawrzyńca Gembickiego z lat 1620-1623, „Przegląd Historyczny" 1991, t. LXXXII, z. 3-4, s. 469-479; W. Biernacki, Biata Góra, s. 333-340; W. Felczak, Historia Wegier, s. 144. 
którego a co wiedzieć jako nie udawano u dworu i nie udają. Już ja z Bethlenem Gáborem praktykuję i wojnę szwedzką rozgrywam i szlachtę do sedycyji wiodę, i wszystko, co jedno cornuti patres [jezuici] mogą wymyślić, czynię. Ja zaś co na to? Iż nulla pallesco culpa, niech mi pan Bóg nie będzie propiutius, że tak sperno i tak się śmieję z tej złości ich i wszystkich innych kalumniatorów, którzy się do tego przykładają, że się muszą pukać do jadu ${ }^{15}$.

W pisanym we wrześniu 1625 r. liście do króla, który wyrażał obawy o wrogie poczynania Bethlena Gábora „przeciwko sobie i temu królestwu”, Jerzy ks. Zbaraski zajął się przede wszystkim sytuacją polityczną na pograniczu południowo-wschodnim. Mówił o konieczności wzięcia w karby Kozaczyzny oraz o poczynaniach Turków i Tatarów. Obawiał się, że jeśli hetman Stanisław Koniecpolski nie zatrzyma pod sztandarami wojska na zimę, to Kozacy rozleją się po całej Ukrainie i nie będą słuchać niczyich rozkazów. Nie pokładał też większych nadziei w kolejnej komisji kozackiej (powołał ją król w lipcu 1625 r.), gdyż przewidywał, że Kozacy jak zawsze przyjmą wszystkie narzucone im warunki, po czym ich nie dotrzymają. Sporo uwagi poświęcił natomiast pan krakowski sojuszowi Zaporoża z Szahin Girejem. Niebezpieczeństwo z tej strony wydało mu się znacznie większe niż zagrożenie ze strony Gustawa Adolfa czy też wspomnianego wcześniej Bethlena Gábora ${ }^{16}$.

Jesienią 1625 r. biskup krakowski Marcin Szyszkowski pisał do Jerzego ks. Zbaraskiego o przepowiedniach astrologicznych, z których wynikało, iż Bethlen Gábor może wkrótce zostać królem Polski. Powiadomił go także o wykryciu spisku protestanckiego, którego celem miało być wyniesienie na tron polski brata króla francuskiego - Gastona. W swojej odpowiedzi Zbaraski starał się bagatelizować obie sprawy. Nie wierzył ani w słowa astrologów, ani w istnienie jakiegoś spisku polskich innowierców, którzy „cives wielcy są, nie myślą o tym, bo są unius libertatis haeredes z nami”. Najpewniej jednak list biskupa krakowskiego wzbudził jego niepokój, o czym zdaje się świadczyć następujące wyznanie: „Toż się i ja boję, by mię nie insimulowano ab utrinque, żem był w Węgrzech i żem do Francyjej posłał dla swych potrzeb czeladnika”. W dalszej części cytowanego listu nie omieszkał książę Jerzy poradzić biskupowi, aby król przestał myśleć o błahostkach, a skupił się na zagrożeniu rządzonego przez siebie państwa ze

${ }^{15}$ J. Zbaraski do Krzysztofa Radziwiłła, Kraków, 3 VIII 1625, „Spisek orleański” z lat 1626-1628, oprac. U. Augustyniak, W. Sokołowski, Warszawa 1990, s. 95-96.

16 J. Zbaraski do Zygmunta III, Pilica, 22 IX 1625, Listy księcia Jerzego Zbaraskiego, s. 96-99. Dodajmy w tym miejscu, że poruszana w listach pana krakowskiego sprawa kozacka znalazła swoje tymczasowe rozwiązanie w narzuconej Kozaczyźnie przez hetmana Stanisława Koniecpolskiego tzw. ugodzie kurukowskiej (6 XI 1625), która przewidywała obniżenie rejestru do sześciu tysięcy ludzi. Ponadto Kozacy zobowiązali się zaniechać „chadzek” na Morze Czarne, przestrzegać porządku i nie wdawać się w żadne konszachty z obcymi państwami. Por. W.A. Serczyk, Na dalekiej Ukrainie. Dzieje Kozaczyzny do 1648 r., Kraków 1984, s. 263; Z. Wójcik, Dzikie pola w ogniu. O Kozaczyźnie w dawnej Rzeczypospolitej, wyd. 2, Warszawa 1961, s. 102-104. 
strony Bethlena Gábora, Turków, Moskwy i Szwecji. Przypomniał także o narastaniu niezadowolenia szlachty z powodu niemożności poskromienia kozackiej swawoli i ulegania przez króla złym doradcom ${ }^{17}$.

W lipcu 1626 r. Jerzy ks. Zbaraski informował króla o zagrożeniu południowej granicy ze strony Bethlena Gábora, Turków, Tatarów i hospodara mołdawskiego. Jego niepokój pogłębiał fakt, że w Małopolsce nie było żadnych sił wojskowych, a bezpieczeństwa Krakowa strzegł podstarości i 20 piechurów. Książę przewidywał, iż w przypadku ataku, w dwa dni miasto znalazłoby się w rękach nieprzyjaciela. Prosił więc króla, aby wydał rozkazy Koniecpolskiemu, nakazując mu przysłać z Ukrainy nad granicę węgierską półtora tysiąca do dwóch tysięcy jazdy, „a najwięcej husarzów, bo rozumiem, że tych najmniejsza opera przeciwko Tatarom być może”. Proponował również zwołanie pospolitego ruszenia województw krakowskiego, sandomierskiego i sieradzkiego, zawezwanie na pomoc piechoty biskupa krakowskiego i ludzi Stanisława Lubomirskiego. Sam Zbaraski obiecywał, iż do zgromadzonych wojsk dołączy swoje nadworne oddziały, aczkolwiek zastrzegał, że nie będzie to łatwe, „bo mnie widzisz WKM, jako daleko ludzi ściągać aż z Ukrainy”. Zgromadzenie na granicy węgierskiej kilku tysięcy żołnierzy (książę przewidywał, że zwykła w takich razach plotka powiększy znacznie ich liczbę) powinno skutecznie zniechęcić Bethlena Gábora do podejmowania jakichś wrogich działań przeciwko Rzeczypospolitej. Do najazdu na Polskę mogłaby go skłonić jedynie klęska Koniecpolskiego w walce z Tatarami. Zbaraski nie dopuszczał jednak do siebie tej myśli, twierdząc, iż chociaż „hetman i 2000 ludzi sobie ujmie, supplebit to zasię Kozakami, którzy bez pochyby do niego pójdą, kiedy Doroszenko już się tam z nim uspokoił”. W tym samym liście książę-kasztelan pisał, iż właśnie otrzymał wiadomość o lądowaniu wojsk szwedzkich w Prusach. Przewidywał stąd zagrożenie dla osoby króla i utrudnienia w handlu gdańskim, bez którego „Polska żadnych dostatków mieć nie może”. Sytuację uznawał Zbaraski za bardzo groźną, gdyż ewentualny sukces w Prusach Gustawa Adolfa mógłby zachęcić do uderzenia na Polskę Bethlena Gábora, który w marcu tego roku ożenił się z Katarzyną Brandenburską, rodzoną siostrą żony władcy Szwecji. Zadawał więc bolesne dla króla pytanie, co robią urzędnicy wojenni w Inflantach, skoro władca Szwecji mógł przerzucić swoje wojska do Prus? Proponował

${ }_{17}$ M. Szyszkowski do J. Zbaraskiego, [X-XI 1625]; J. Zbaraski do M. Szyszkowskiego, [X-XI 1625], „Spisek orleański”, s. 98-100, 102-104. Warto dodać, iż braci Zbaraskich od dawna pomawiano o konszachty z Bethlenem Gáborem w sprawie jego ewentualnej elekcji na tron polski. I chociaż nie wydaje się możliwe, aby książę Jerzy rzeczywiście popierał kandydaturę Bethlena (dumny magnat zapewne z trudem zniósłby jego królowanie), to nie jest wykluczone, że miał coś wspólnego z pomysłem wyniesienia na tron polski kandydata francuskiego. Jest jednak również sprawą oczywistą i nie podlegającą dyskusji, iż (wbrew opiniom niektórych historyków przypisujących magnackiej opozycji zbrodnicze zamiary wobec króla i jego rodziny) brat Ludwika XIII mógłby starać się o koronę polską dopiero po naturalnej śmierci Zygmunta III. 
również natychmiastowe wezwanie do tej prowincji dwóch tysięcy ludzi, którzy wcześniej zostali wysłani do Inflant, „bo Litwa już tam nic ciężkiego ucierpieć nie może”18.

Kilka dni później Zbaraski ostrzegał króla, że Rzeczypospolitej grozi najazd ze strony Bethlena Gábora i Tatarów Szahin Gireja. Obaj mieliby uderzyć w jednym czasie, korzystając z tego, że Gustaw Adolf rozpoczął działania wojenne w Prusach. Książę Jerzy obawiał się ataku władcy Siedmiogrodu na Kraków, a Tatarów na Ukrainę. Ponieważ wojska hetmana Koniecpolskiego znajdowały się daleko na kresach, Zbaraski ponownie prosił króla o przysłanie na granicę węgierską dwóch tysięcy jazdy kwarcianej, zwołanie pospolitego ruszenia województwa krakowskiego, wyznaczenie odpowiedniego wodza i danie mu na pierwsze wydatki kilkudziesięciu tysięcy złotych ze skarbu radomskiego. Radził przy tym powierzenie dowództwa obrony Małopolski Stanisławowi Lubomirskiemu, „który i kilka set człeka swego zaraz może mieć i tu w Podgórzu ma powinowactwa i clientellą swoję mógłby prędko co ludzi zebrać". Zbaraski nalegał na pośpiech, gdyż na Spiszu widziano posła szwedzkiego jadącego do Bethlena Gábora. Twierdził jednak stanowczo, że nie będzie można zorganizować skutecznej obrony bez przysłania z Ukrainy regularnych oddziałów jazdy koronnej. Radził wreszcie, aby Koniecpolski przesunął swoją armię bardziej na zachód i stanął między Kuczmańskim a Czarnym szlakiem ${ }^{19}$.

W dniu 1 sierpnia 1626 r. Jerzy ks. Zbaraski pisał, że właśnie otrzymał rozkazy od króla, aby w porozumieniu z innymi panami małopolskimi myślał o obronie Krakowa w przypadku agresji ze strony Bethlena Gábora. Książę nie posiadał się z oburzenia. Twierdzil, że obronę stolicy powinna obmyślić Rzeczpospolita, a nie prywatni obywatele. Zebrana naprędce czeladź nie zatrzyma bowiem nieprzyjaciela dysponującego regularnym wojskiem. Powinność obrony miasta i zamku krakowskiego spoczywa co prawda na wojewodzie krakowskim, ale bronić Krakowa ma nie swoimi prywatnymi siłami, tylko wojskami Rzeczypospolitej. Stan umocnień stolicy jest zaś tak żałosny, że nawet pięć czy sześć tysięcy piechoty nie obroni miasta („Nie wspominam też innych tysiąca defektów samych murów, którebym na wielu miejscach takie pokazal, żeby nogą wybił”). Trzeba zatem zorganizować obronę Krakowa przed jego murami. Radził więc książę Jerzy sięgnięcie do środków wspomnianych w jego wcześniejszych listach. Sam również deklarował pomoc, ale zastrzegał, że w przypadku nagłego ataku Siedmiogrodzian nie zdąży ściągnąć na czas swoich chorągwi z Ukrainy: „Ja tych trochę

18 J. Zbaraski do Zygmunta III, Kraków, 18 VII 1626, Listy księcia Jerzego Zbaraskiego, s. 104-107. Dodajmy w tym miejscu, że w od końca czerwca do końca lipca 1626 r. wojska szwedzkie opanowały Piławę, Braniewo, Frombork, Tolkmicko, Elbląg, Malbork i Tczew. Por. Z. Anusik, Gustaw II Adolf, wyd. 2, Wrocław 2009, s. 157-159; M. Roberts, Gustavus Adolphus. A History of Sweden 1611-1632, vol. II (1626-1632), London-New York-Toronto 1958, s. 321-327.

19 J. Zbaraski do Zygmunta III, Kraków, 22 VII 1626, Listy księcia Jerzego Zbaraskiego, s. 107-108. 
ludzi, których mam tak daleko odległych, nie mogę prędko dosiąc, więc i rozdzielić się z niemi muszę, bo i tam chudoby swojej odbieżeć nago, pod tak prędkim i ustawicznym nieprzyjacielem, byłaby wielka dementia". Wytknął ponadto królowi, że jego życzenie, żeby kilku prywatnych obywateli powstrzymało wroga, który z cesarzem „dobrze się próbowal, et non sine gloria i wielkiego zysku... nie tylko jest sperandum, ale neque i mente habendum". Objawioną przez króla chęć zastawienia klejnotów koronnych przyjął ze zrozumieniem, ale nie widział nikogo, kto miałby gotówkę i mógłby ją wyłożyć na zastaw. Radził zatem wziąć ze skarbu radomskiego chociaż 30 tys. złotych i przekazać te pieniądze Stanisławowi Lubomirskiemu, aby ten zaciągnął choć tysiąc koni. Jeśli z Ukrainy przyszłoby dwa tysiące kwarcianych (o czym pisał już wcześniej), to razem z pospolitym ruszeniem krakowskim nad granicą mogłoby stanąć do sześciu tysięcy ludzi, a stugębna fama z pewnością podwoiłaby te siły. „Posłałem ja do swoich na Wołyń i Ukrainę, także i mój brat, aby się tu co prędzej nademknęli bliżej, cóż ja wiem, jeśli przejścia Tatarowie dopuszczą, bo i tych już co godzinę wyglądać trzeba”. Kasztelan krakowski zapewniał króla, że jeśli nadejdzie Bethlen Gábor, to będzie robił wraz z bratem co w jego mocy, licząc na wsparcie ze strony województwa krakowskiego, sandomierskiego i lubelskiego. Swoim zwyczajem nie omieszkał jednak w dość przykrych słowach przypomnieć władcy, że ten nigdy nie potrafił docenić zasług braci Zbaraskich dla Rzeczypospolitej. Książę Jerzy podkreślał, że wielokrotnie stawiał się do obozu hetmanów, a przychodził

nie ze stem ani z 50 koni jako drudzy, ale z pułkiem znacznym [...] Potem teraz po kilka razów rok po roku jaka gromada ludzi moich i brata mego przychodziła do imć pana wojewody sandomierskiego [Stanisława Koniecpolskiego], dał świadectwo dobre Jegomość, jako człowiek cnotliwy et non invidus virtuti, gdzie i krwią swoją skropili dobrze jedni, posługę WKM i Rzeczypospolitej, drudzy żywot położyli [...] I to mnie cieszy, żem więcej uczynił, i tysiąc razów więcej, lubo się moim nieprzyjaciołom będzie zdało, że to arroganter rzekę, niźli ci, którycheś WKM, sine mea dali Bóg invidia, Bóg mi sam świadkiem, ubogacićeś raczył ad nauseam, ci niechaj i teraz pokazują miłość swoję, którzy jako żywo ani sobą experimentum dederunt, ani kosztem najmniejszym Rzeczypospolitej nie ratowali ${ }^{20}$.

Kilka dni później pan krakowski przesłał królowi uspokajające wieści odnośnie do Bethlena Gábora, gdyż okazało się, iż jego wojska nie wkroczyły jeszcze na terytorium węgierskich komitatów pozyskanych od Habsburgów na mocy traktatów pokojowych z Nikolsburga i Wiednia. Pomimo wyraźnego polecenia Zygmunta III, Zbaraski wstrzymał się więc z wysłaniem listu do księcia siedmiogrodzkiego, gdyż jego zdaniem niezręcznie byłoby pytać Bethlena, „dlaczego wojsko do siebie gromadzi”, skoro robi to w głębi kraju. Książę zamierzał wysłać posłańca do władcy Siedmiogrodu dopiero

${ }^{20}$ J. Zbaraski do Zygmunta III, Kraków, 1 VIII 1626, Listy księcia Jerzego Zbaraskiego, s. 108-110. 
w wypadku, gdyby pojawił się on w Koszycach ${ }^{21}$. W połowie sierpnia 1626 r. pan krakowski przybył na sejmik proszowski, który uchwalił podatki i podjął przygotowania do odparcia spodziewanego ataku na województwo krakowskie ze strony Bethlena Gábora $^{22}$.

W tym samym czasie Jerzy ks. Zbaraski przekazał królowi szczegółowe informacje o wojskach Mansfelda i Jana Ernesta I ks. sasko-weimarskiego, które po opuszczeniu służby Bethlena Gábora rozłożyły się w Cieszynie, Opawie i kilku przyległych miasteczkach. Ich sytuacja była trudna, gdyż obaj wodzowie zmarli, a niemal zewsząd zagrażały im siły cesarskie. Formalnie byli to żołnierze ligi antyhabsburskiej kierowanej przez króla duńskiego Chrystiana IV. Gdyby jednak ten nie był w stanie przyjść im z pomocą, rozważali możliwość wstąpienia do służby cesarskiej, przebijania się na północ do Brandenburgii lub zaciągnięcia się do armii Gustawa II Adolfa. Zdaniem Zbaraskiego było ich 13 tys. lub nawet nieco więcej. Na razie przystąpili do umacniania swoich pozycji na Śląsku cieszyńsko-opawskim, gdzie zamierzali bronić się przed cesarzem. Rozważali jednak również możliwość ruszenia na północ na spotkanie z siłami króla duńskiego, jeśli ten zdecydowałby się przyjść im z pomocą. Książę Jerzy uważał, że Bethlen Gábor będzie obserwował ich poczynania i w zależności od rozwoju sytuacji albo utrzyma pokój z cesarzem, albo go zerwie. Jednocześnie książę ostrzegał króla, że gdyby ludzie Mansfelda zawarli porozumienie ze Szwedami lub dostali rozkazy od swojej ligi, bardzo łatwo mogliby przebić się do Prus i po 12 dniach stanąć pod Toruniem. Jeśli zaś Jakob De la Gardie zawarł rozejm z Litwinami tylko po to, aby przerzucić swoje wojska z Inflant pod Królewiec, to wszystko to razem miałoby fatalne wręcz skutki dla armii Koniecpolskiego. Zbaraski ostrzegał też króla, żeby nie liczył zbytnio na skuteczność zaciągów Gerarda Denhoffa na Śląsku, ponieważ cesarz zabronił werbowania tu ludzi do innych armii poza armią Albrechta von Wallensteina. Był również zdecydowanie przeciwny zaciągom do armii koronnej czynionym wśród Mansfeldczyków, gdyż tym ostatnim po prostu nie ufał. W obliczu ponownego zagrożenia Krakowa nie pokładał żadnych nadziei w ewentualnych uchwałach podatkowych sejmiku proszowskiego (ze względu na wyniszczenie majątków szlacheckich, spadek cen zboża i niedostatek gotowego pieniądza), ale prosił króla o przysłanie 200 piechurów do obrony zamku

${ }^{21}$ J. Zbaraski do Zygmunta III, Kraków, 5 VIII 1626, Listy księcia Jerzego Zbaraskiego, s. 111-112. Warto dodać, że Zbaraski nie mógł wówczas wiedzieć, że Bethlen Gábor w początkach sierpnia 1626 r. wypowiedział wojnę Ferdynandowi II. Na wieść o porażkach wojsk duńskich w Niemczech władca Siedmiogrodu zawarł jednak rozejm z cesarzem, a 30 XII 1626 r. jego wysłannicy podpisali traktat pokojowy w Preszburgu. Na mocy jego postanowień Bethlen Gábor ostatecznie wycofał się z antyhabsburskiej koalicji. Por. M. Roberts, Gustavus Adolphus, s. 329; W. Felczak, Historia Wegier, s. 144.

${ }^{22}$ Por. Uchwaty sejmiku województwa krakowskiego w Proszowicach 14 sierpnia 1626 r., [w:] Akta sejmikowe województwa krakowskiego, t. II (1621-1648), wyd. A. Przyboś, Wrocław-Kraków 1953, s. 58-61 (pod przywołanymi tu uchwałami widnieje podpis Jerzego ks. Zbaraskiego). 
krakowskiego. Posłał też po posiłki do biskupa krakowskiego i Stanisława Lubomirskiego. Sam także zamierzał ściągnąć do stolicy swoją piechotę „,cokolwiek jej jedno w tym kraju mam”. Książę Jerzy był przekonany, że podjęte przez niego kroki powinny zabezpieczyć Kraków przed niespodziewanym uderzeniem ze strony Bethlena Gábora lub Mansfeldczyków. Uważał jednak, że dla bezpieczeństwa stolicy potrzebna byłaby stała obecność starosty krakowskiego, którym był wówczas Gabriel Tarnowski²3.

Przejęcie dóbr ziemskich po bracie (Krzysztof ks. Zbaraski zmarł w Końskowoli 6 marca 1627 r.) i skupienie w swoim ręku całej fortuny rodu zwiększyło wyraźnie znaczenie polityczne Jerzego ks. Zbaraskiego, ale z pewnością nie rekompensowało mu ogromu poniesionej straty. Pogrążony w bólu i żałobie, pisał jednak w połowie marca do króla, przypominając o konieczności przyspieszenia zaciągów do armii tak w Prusach, jak i na Ukrainie. Ostrzegał przed wiosenną ofensywą szwedzką, prosząc o jak najszybsze wysłanie posiłków dla hetmana Koniecpolskiego. Przekazał też Zygmuntowi III wiadomość, że u Bethlena Gábora przebywają posłowie duński, angielski, holenderski, wenecki, szwedzki oraz wysłannik palatyna Renu Fryderyka V. I chociaż rozmawiają głównie o sprawach niemieckich, to gdyby Koniecpolski został pobity w Prusach, „wsiądą zaraz na konie wszyscy i Mansfeldczykowie, co tu tak blisko pod bokiem są, zaraz by pewnie na Kraków skoczyli, który co ma za opatrzność, dobrze to WKM wiedzieć raczysz". Zbaraski prosił więc króla o jak najszybsze zwołanie nowego sejmu i obmyślenie nowych źródeł finansowania wydatków wojennych, bo „o podatkach żadnych więcej myśleć nie potrzeba, bo ich i wziąć skąd nie będzie"24.

W maju 1627 r. Jerzy ks. Zbaraski informował króla o sytuacji w Niemczech i o poczynaniach dawnej armii Mansfelda na Śląsku cieszyńsko-opawskim. Według jego informacji król duński miał pod sztandarami tylko 10 tys. jazdy i cztery tysiące piechoty. W najbliższym czasie miało mu jednak przyjść na pomoc sześć tysięcy piechoty angielskiej. Dysponując takimi siłami, Chrystian IV nie mógł wysłać żadnych posiłków na Śląsk. Po pierwsze bowiem, na jego drodze stała armia Ligi Katolickiej dowodzona przez Johana von Tilly'ego, a po drugie, Francja i Wenecja miały mu wstrzymać wypłacane

${ }^{23}$ J. Zbaraski do Zygmunta III, Kraków, 22 II 1627, Listy księcia Jerzego Zbaraskiego, s. 118-121. Por. też J. Maroń, Militarne aspekty wojny trzydziestoletniej na Śląku, Wrocław 2000, s. 113-117 (tu o poczynaniach wojsk Ernesta von Mansfelda na Śląsku w kampanii 1626 r.); M. Roberts, Gustavus Adolphus, s. 329; Z. Anusik, Kasztelan krakowski Jerzy ks. Zbaraski, s. 106-107.

${ }^{24}$ J. Zbaraski do Zygmunta III, Kraków, 14 III 1627, Listy księcia Jerzego Zbaraskiego, s. 124-125. Dodajmy w tym miejscu, że po wycofaniu się z wojny z cesarzem, Bethlen Gábor wyraźnie zmierzał do uzyskania korony polskiej. Chciał ją zdobyć siłą, korzystając ze wsparcia Gustawa II Adolfa oraz Moskwy. Z tego względu w latach 1627-1629 był postrzegany w Rzeczypospolitej jako potencjalny agresor, który w sprzyjających okolicznościach może dokonać niespodziewanego najazdu. Por. W. Felczak, Historia Węgier, s. 144-145. W kwestii majątków przejętych przez pana krakowskiego po śmierci młodszego brata por. Z. Anusik, Kasztelan krakowski Jerzy ks. Zbaraski, s. 108-114. 
dotąd subsydia. W tej sytuacji całą swoją nadzieję lokowali Mansfeldczycy w Bethlenie Gáborze, który jako jedyny mógł udzielić im militarnego wsparcia w rozgrywce z wojskami cesarskimi ${ }^{25}$.

W czerwcu tego samego roku Zbaraski informował króla, że Bethlen Gábor pojednał się ostatecznie z cesarzem i zrezygnował z zamiaru zerwania pokoju preszburskiego. Pisał także o niepokojach na pograniczu z Turcją i wielkiej wyprawie kozackiej na Morze Czarne ${ }^{26}$. Kilkanaście dni później książę Jerzy ponownie pisał do króla, nalegając na jak najszybsze zwołanie sejmu. Nie obawiał się wówczas zagrożenia ze strony Porty, gdyż uważał, że Turcy nie mogą podjąć żadnych działań przeciwko Polsce z powodu wojny z Persją. Również Bethlen Gábor „roku tego pewnie quiescet i będzie patrzył eventum tych wojsk luterskich z katolikami, więc i tureckiej wojny z Persami” ${ }^{27}$.

W końcu września 1628 r. Jerzy ks. Zbaraski ubolewał nad sukcesami wojsk szwedzkich w Prusach. Odradzał jednak zwołanie pospolitego ruszenia. Wyprowadzenie z województw ruskich pocztów magnackich i szlachty byłoby bowiem nieostrożne ze względu na spodziewane starcie Szahina Gireja i Kozaków z wojskami chana Dżanibeka II. W razie ich klęski na Ukrainę z pewnością spadnie najazd tatarski, a kwarciani regimentarza Stefana Chmieleckiego są za słabi, aby samodzielnie go odeprzeć. Nie należy też lekceważyć zagrożenia ze strony Bethlena Gábora, który patrzy w kierunku Małopolski i „dyba jako złodziej na jarmark, żeby co jeno załapić mógł”. W tej sytuacji książę Jerzy radził, aby Koniecpolski przeszedł do działań defensywnych i skupił swoich ludzi w umocnionym obozie. Gdyby Szwedzi poszli na Toruń, Koniecpolski może iść za nimi, szarpiąc ich i unikając walnej bitwy. Pan krakowski nalegał na zwołanie sejmu. Uważał bowiem, że trzeba znaleźć nowe sposoby finansowania wojny. $\mathrm{Na}$ razie jednak, nie widząc innego wyjścia z sytuacji, radził królowi, aby rozesłał uniwersały do Wielkopolan i Mazowszan, żeby „kupili się do imć pana hetmana” ${ }^{28}$. Sam Zbaraski odmówił jednak w październiku królowi przysłania do Prus swoich prywatnych chorągwi z Ukrainy, wymawiając się zbyt dużą odległością miejsca stacjonowania tych oddziałów od pruskiego teatru działań wojennych oraz brakiem pieniędzy. Powtórzył natomiast swoją prośbę o zwołanie sejmu, gdyż wszystkie inne nadzieje królewskie uznał za „bardzo płonne”29.

${ }^{25}$ J. Zbaraski do Zygmunta III, Kraków, V 1627, Listy księcia Jerzego Zbaraskiego, s. 127-130.

${ }^{26}$ J. Zbaraski do Zygmunta III, Kraków, 13 VI 1627, Listy księcia Jerzego Zbaraskiego, s. 131-132.

${ }_{27}$ J. Zbaraski do Zygmunta III, Kraków, 29 VI 1627, Listy księcia Jerzego Zbaraskiego, s. 132-133.

${ }^{28}$ J. Zbaraski do Zygmunta III, Kraków, 27 IX 1628, Listy księcia Jerzego Zbaraskiego, s. 142-145. Wypada zwrócić w tym miejscu uwagę na trafność przewidywań kasztelana krakowskiego odnośnie do działań wojennych w Prusach, gdzie Koniecpolski rzeczywiście nie dał Gustawowi II Adolfowi szansy na stoczenie bitwy w otwartym polu, stanął w umocnionym obozie pod Grudziądzem i nie miał zamiaru go opuszczać, a tymczasem zagony polskiej jazdy niszczyły okolicę, uniemożliwiając Szwedom zdobywanie żywności i furażu. Por. Z. Anusik, Gustaw II Adolf, s. 183; M. Roberts, Gustavus Adolphus, s. 389-390.

${ }^{29}$ J. Zbaraski do Zygmunta III, Pilica, 31 X 1628, Listy księcia Jerzego Zbaraskiego, s. 145. 
W początkach kwietnia 1629 r. Zbaraski pisał do króla, informując go o ponownym zagrożeniu Krakowa przez Bethlena Gábora. U władcy Siedmiogrodu przebywać mieli bowiem posłowie szwedzki, turecki i moskiewski, którzy nakłaniali go do uderzenia na Polskę. Pan krakowski tłumaczył postępowanie Stanisława Lubomirskiego, który odmówił prośbie króla, aby zajął się przygotowaniem obrony Małopolski na wypadek agresji ze strony Bethlena Gábora. Twierdził, że podjęcie się takiego dzieła prywatnymi siłami jednego obywatela byłoby oczywistym szaleństwem. Radził zatem przysłać nad granicę węgierską przynajmniej tysiąc jazdy kwarcianej i kilkadziesiąt tysięcy florenów. Wraz z ludźmi Lubomirskiego, „których też ma, i może mieć kilkanaście set tak piechoty, jako i jazdy", byłaby to siła wystarczająca do powstrzymania uderzenia Siedmiogrodzian. Na wszelki wypadek Zbaraski proponował jednak, aby król rozesłał również uniwersały na pospolite ruszenie do województw krakowskiego, sandomierskiego i sieradzkiego, a Stefanowi Chmieleckiemu rozkazał, żeby Kozakom rejestrowym kazał uderzyć na Siedmiogród, gdyby Bethlen zdecydował się zaatakować Rzeczpospolitą ${ }^{30}$.

Była to ostatnia wzmianka o Gabrielu Bethlenie w korespondencji kasztelana krakowskiego. Dnia 26 września 1629 r. Rzeczpospolita zawarła bowiem rozejm ze Szwecją w Altmarku (Starym Targu). W dniu 15 listopada tego samego roku zmarł natomiast niespodziewanie władca Siedmiogrodu. Zagrożenie granic państwa ze strony zakarpackiego sąsiada na jakiś czas zniknęło. Przyznać trzeba, że Jerzy ks. Zbaraski, mieszkając na stałe w Krakowie, dość uważnie śledził poczynania Bethlena Gábora. Ten ostatni interesował go przynajmniej z kilku powodów. Po pierwsze, jako wierny i oddany sułtanowi lennik turecki. Po drugie, jako szwagier wojującego z Rzecząpospolitą Gustawa II Adolfa. Posiadając dobra w województwie krakowskim, książę na Zbarażu obawiał się bowiem ewentualnej agresji Bethlena na Małopolskę właściwą. Po trzecie, książę Jerzy, będąc jednym z przywódców opozycji antykrólewskiej, widział we władcy Siedmiogrodu potencjalnego sojusznika w walce z Zygmuntem III. Po czwarte wreszcie, pan krakowski zdawał sobie sprawę z tego, że Bethlen Gábor chętnie sięgnąłby w sprzyjających okolicznościach po koronę polską. Ponieważ zaś pod koniec życia książę Jerzy sam prawdopodobnie myślał o zdobyciu krakowskiego tronu dla siebie, musiał widzieć w siedmiogrodzkim władcy niebezpiecznego rywala. Niezależnie zaś od wszystkiego, Jerzy ks. Zbaraski (w porozumieniu z bratem Krzysztofem) opracował własny plan obrony województwa krakowskiego przed ewentualnym najazdem Gabriela Bethlena, który później, w okresach zagrożenia granic państwa, kilkakrotnie przedstawiał królowi ${ }^{31}$.

${ }^{30}$ J. Zbaraski do Zygmunta III, Kraków, 9 IV 1629, Listy księcia Jerzego Zbaraskiego, s. 148-150.

31 Por. Z. Anusik, Gustaw II Adolf, s. 187-188; idem, Ksiązęta Jerzy i Krzysztof Zbarascy wobec problemów potudniowo-wschodniego pogranicza Rzeczypospolitej w drugim i trzecim dziesięcioleciu XVII wieku, „Przegląd Nauk Historycznych” 2016, R. XV, nr 2, s. 182. http://dx.doi.org/10.18778/1644$-857 X .15 .02 .05$ 


\begin{abstract}
Prince Jerzy Zbaraski (1574-1631) was one of the most outstanding Polish politicians of the first half of $17^{\text {th }}$ century. Since 1620 he held the prestigious office of castellan of Kraków. He was a recognized leader of the opposition in the second half of the reign of Sigismund III. Living permanently in Kraków, he carefully observed the actions of Bethlen Gábor, ruling in Transylvania, whom he considered as a faithful vasal of the Turkish Sultan. Zbaraski's attitude to the Bethlen was ambivalent. On the one hand, the prince considered the ruler of Transylvania as a dangerous neighbor of the Commonwealth and warned the Polish king against him. On the other hand, he saw him as a potential ally against his own monarch. However, Bethlen's efforts to obtain the Polish crown made the castellan of Kraków, dreaming of the Polish throne himself, perceive this neighbor with increasing reluctance. The article attempts to trace the attitude of prince Jerzy Zbaraski to the ruler of Transylvania in the years 1619-1629. The starting point for these considerations is the battle of Humienne (Hommonai) fought on November 23, 1619 (Jerzy Zbaraski was a resolute opponent of sending Polish troops to Transylvania). The final chord is the unexpected death of Bethlen Gábor, who died on November 15, 1629.
\end{abstract}

\title{
Keywords
}

Prince Jerzy Zbaraski, Bethlen Gábor, Sigismund III, Transylvania, Polish-Lithuanian Commonwealth in the first half of $17^{\text {th }}$ century. 